\title{
Purification and Some Properties of a Thermostable Lipase from Humicola lanuginosa No. 3
}

\author{
IBRAHIM Che Omar, Mitsunori HAYASHI \\ and Shiro NAGAI* \\ Department of Fermentation Technology, Faculty of Engineering, \\ Hiroshima University, Saijo-cho, Higashi-Hiroshima 724, Japan
}

Received May 12, 1986

\begin{abstract}
A thermostable lipase from Humicola lanuginosa No. 3 was purified by means of acetone precipitation and successive chromatographies on Sephadex G-75, DEAE Sepharose CL-6B and hydroxyapatite columns. The enzyme was purified about 150 -fold with a yield of $15.0 \%$ and a specific activity of about $3000 \mathrm{U} / \mathrm{mg}$ protein. The purified enzyme showed a single protein band on polyacrylamide gel electrophoresis. Its molecular weight was estimated to be 39,000 . on both sodium dodecyl sulfate polyacrylamide gel electrophoresis and gel filtration on Sephadex G-100, suggesting that the enzyme was a monomer. Its isoelectric point was $\mathrm{pH}$ 6.6. The optimum $\mathrm{pH}$ and temperature were 7.0 and $45^{\circ} \mathrm{C}$, respectively. The enzyme was stable over a $\mathrm{pH}$ range of 5 to 9 $\left(45^{\circ} \mathrm{C}, 24 \mathrm{hr}\right)$, and its activity was maintained at $60^{\circ} \mathrm{C}$ for about $20 \mathrm{hr}$. The activity was inhibited by $\mathrm{Co}^{2+}, \mathrm{Cu}^{2+}, \mathrm{Ni}^{2+}, \mathrm{Hg}^{2+}$ and $\mathrm{Sn}^{2+}$, and slightly affected by $\mathrm{Zn}^{2+}, \mathrm{Mg}^{2+}$, EDTA and sodium dodecyl sulfate. The $\mathrm{Km}$ value for trilaurin $\left(45^{\circ} \mathrm{C}\right)$ was $14.2 \mathrm{mg} / \mathrm{ml}$. The enzyme was specific for substrates containing a C12 fatty acid component. Analysis of hydrolyzates of triolein and olive oil after the lipase reaction revealed that Humicola lanuginosa No. 3 produced a 1,3 positional specific lipolytic enzyme.
\end{abstract}

Many reports on the purification of microbial lipases $^{1 \sim 11}$ ) $(\mathrm{EC}$ 3.1.1.3, glycerol ester hydrolase) have been published, and their properties have been elucidated. These purified lipases show wide variations of properties, e.g., substrate specificity, thermostability and activator requirements.

We screened 20 thermophilic fungi for extracellular lipolytic enzyme production. From the results obtained, Humicola lanuginosa No. 3 was selected as a potent producer of a lipase. The amount of intracellular lipase was found to be insignificant.

In order to obtain better and more comprehensible information on our thermostable lipase, its purification was attempted. In this report we described the results of the purification and some properties of the lipase from H. lanuginosa No. 3.

\section{MATERIALS AND METHODS}

Microorganism. Humicola lanuginosa No. 3, maintained on a potato dextrose agar slant at $4^{\circ} \mathrm{C}$, was used.

Cultivation. The organism was cultivated in a 10 liter jar fermentor (L. E. Marubishi Co., Ltd.) with a working volume of 5 liters. The medium composition was as follows ( $\%$ ): 1.0 sorbitol; 1.0 corn steep liquor; $0.5 \mathrm{NaCl}$; $0.01 \mathrm{CaCl}_{2} \cdot 2 \mathrm{H}_{2} \mathrm{O} ; 0.3$ Tween 80 ; and 0.2 Silicone $\mathrm{Km}-70$ (pH 7.0). The agitation and aeration rates were $200 \mathrm{rpm}$ and $1.0 \mathrm{vvm}$, respectively, with an inoculum size of $2.5 \%$ $(v / v)$. The incubation temperature was set at $45^{\circ} \mathrm{C}$.

Enzyme assay. Lipase activity was determined by the olive oil-polyvinyl alcohol emulsion method of Yamada and Machida. ${ }^{12)}$ The reaction mixture consisting of $5 \mathrm{ml}$ of the emulsion, $4 \mathrm{ml}$ of $0.2 \mathrm{M}$ sodium phosphate buffer $(\mathrm{pH}$ 7.0) and $1 \mathrm{ml}$ of the enzyme solution was incubated for $30 \mathrm{~min}$ at $45^{\circ} \mathrm{C}$. The enzyme reaction was terminated by the addition of $20 \mathrm{ml}$ of an acetone-ethanol mixture $(1: 1$, $\mathrm{v} / \mathrm{v})$. Free fatty acid liberated was titrated with $0.05 \mathrm{~N}$ sodium hydroxide solution using phenolphthalein as an

* To whom correspondence should be addressed. 
indicator. One unit of lipase activity was defined as the amount which liberated $1 \mu \mathrm{mol}$ of acid per min at $45^{\circ} \mathrm{C}$.

Protein assay. In the column effluent, protein was determined by measuring the absorbance at $280 \mathrm{~nm}$. In the pooled sample, it was determined by the method of Lowry et $a .^{13)}$ with bovine serum albumin as the standard.

Purification of the lipase. All the procedures were performed at $4^{\circ} \mathrm{C}$ unless otherwise stated.

(a) Acetone precipitation. Culture broth $(400 \mathrm{ml})$ taken from the fermentor was centrifuged at $1650 \times g$ for $30 \mathrm{~min}$ to remove the mycelium. To the supernatant was added cold acetone to a final concentration of $80 \%(\mathrm{v} / \mathrm{v}) .{ }^{14)}$ After standing overnight, the precipitate formed was collected by centrifugation at $6600 \times g$ for $30 \mathrm{~min}$. The resulting precipitate was washed with acetone twice and then recentrifuged. The final precipitate was dissolved in $0.05 \mathrm{M}$ sodium phosphate buffer ( $\mathrm{pH}$ 7.0) and undissolved materials were removed by centrifugation.

(b) Sephadex G-75 gel filtration. The sample from step (a) was applied on a column $(2.6 \times 84.0 \mathrm{~cm})$ of Sephadex G-75 equilibrated with $0.05 \mathrm{~m}$ phosphate buffer ( $\mathrm{pH} 7.0$ ), and then the enzyme was eluted with the same buffer. The flow rate was adjusted to $94 \mathrm{ml} / \mathrm{hr}$ with a fraction volume of $4.6 \mathrm{ml}$. Fractions showing lipase activity were pooled for protein and activity determinations.

(c) DEAE Sepharose CL-6B chromatography (1). The enzyme solution from step (b) was concentrated with an ultrafiltration membrane (Toyo ultrafilter, MW 10,000) before its application to a column $(2 \times 37.5 \mathrm{~cm})$ of DEAE Sepharose CL-6B. The column was equilibrated with $0.05 \mathrm{M}$ phosphate buffer $(\mathrm{pH} 7.0)$ and then washed with 2 bed volumes of the same buffer. The enzyme was eluted with a linear $\mathrm{NaCl}$ gradient ( 1 liter), from zero to $0.3 \mathrm{M}$, in the same buffer. The flow rate was adjusted to $63 \mathrm{ml} / \mathrm{hr}$ with a fraction volume of $6.9 \mathrm{ml}$. Lipase activity was eluted in fractions $58 \sim 62$. The latter fractions were pooled and then subjected to PAGE, on which 3 bands were observed, therefore the same procedure as in step (c) was repeated in step (d).

(d) DEAE Sepharose CL-6B chromatography (2). The enzyme from step (c) was dialyzed overnight against $0.05 \mathrm{M}$ phosphate buffer $(\mathrm{pH}$ 7.0). It was then centrifuged $(8900 \times g, 30 \mathrm{~min})$ and concentrated by ultrafiltration (as above). The sample was applied to a column $(1.5 \times$ $15.5 \mathrm{~cm}$ ) previously equilibrated and washed with the same buffer. The enzyme was eluted with a linear $\mathrm{NaCl}$ gradient ( 0.6 liters), from zero to $0.2 \mathrm{M}$, in the same buffer. The flow rate was adjusted to $35 \mathrm{ml} / \mathrm{hr}$ with a fraction volume of $4.0 \mathrm{ml}$. Lipase activity was eluted in fractions $56 \sim 78$. Two bands were observed on PAGE, thus step (e) was performed.

(e) Hydroxyapatite chromatography. The enzyme from step (d) was dialyzed overnight against $0.01 \mathrm{M}$ phosphate buffer ( $\mathrm{pH}$ 7.0). The sample was applied to a column $(0.9 \times 16.5 \mathrm{~cm})$ previously equilibrated and washed with
$0.01 \mathrm{~m}$ phosphate buffer. The enzyme was eluted with a linear phosphate gradient ( 0.6 liters), from 0.01 to $0.2 \mathrm{M}$, in $0.01 \mathrm{M}$ phosphate buffer. The flow rate was adjusted to $17.6 \mathrm{ml} / \mathrm{hr}$ with a fraction volume of $4.0 \mathrm{ml}$. The lipase activity was eluted in fractions $29 \sim 35$, which were used as the enzyme source for further studies.

Polyacrylamide gel electrophoresis. The enzyme purity was confirmed by disc gel electrophoresis according to Davis. ${ }^{15)}$ The enzyme solution was placed on $7 \%$ polyacrylamide gels and then subjected to electrophoresis at pH 6.8 for $2 \mathrm{hr}$ with a constant current of $2 \mathrm{~mA}$ per tube $\left(0.2 \mathrm{~cm}^{2}\right)$. Coomassie brilliant blue R-250 $(0.2 \%)$ in a $50 \%$ methanol-7.5\% acetic acid aqueous mixture was used as a dye. Protein band(s) were detected after decolorization with a $2 \%$ methanol- $7.5 \%$ acetic acid aqueous mixture.

Molecular weight determination. The molecular weight was determined by sodium dodecyl sulfate-polyacrylamide gel electrophoresis (SDS-PAGE) according to the method of Weber and Osborn ${ }^{16)}$ and by gel filtration on a Sephadex G-100 column according to the method of Andrews. ${ }^{17)}$

Isoelectric point determination. The isoelectric point was estimated by PAGE with $2 \%$ Ampholine $(\mathrm{pH} 3.5 \sim 10.0)$ in a $5 \%$ gel $(5 \times 100 \mathrm{~mm}$ gel size $)$ according to the method of Horio and Yamashita. ${ }^{18)}$ Isoelectric focusing electrophoresis was carried out for $5 \mathrm{hr}$ at a constant voltage of $200 \mathrm{~V}$ at $4{ }^{\circ} \mathrm{C}$. The gel was stained with Coomassie brilliant blue G-250.

Hydrolysis of natural oils, triglycerides and monoesters of fatty acids. Reaction mixtures containing $1.0 \mathrm{ml}$ of a substrate, $4.0 \mathrm{ml}$ of $0.2 \mathrm{M}$ sodium phosphate buffer $(\mathrm{pH}$ 7.0) and $0.1 \mathrm{ml}$ of the enzyme solution (40 units) were incubated at $45^{\circ} \mathrm{C}$ for $2 \mathrm{hr}$ with shaking at 100 oscillations per min. The reaction was terminated by adding $20 \mathrm{ml}$ of an acetone-ethanol mixture $(1: 1, \mathrm{v} / \mathrm{v})$, and then the free fatty acid liberated was determined by the titration method described above.

Hydrolysis of triolein or olive oil in the positional specificity determination. The reaction mixture was similar to as described above. After incubation, $25 \mathrm{ml}$ of diethyl ether was added to a reaction mixture to stop the reaction and to extract the products. The extraction was conducted rapidly and the extract was kept in a freezer until use to prevent spontaneous isomerization of the partial glycerides. The products were then analyzed by thin layer chromatography (TLC) on silica gel (60 F254; Merck \& Co., Inc., U.S.A.). The solvent system for the TLC analysis consisted of petroleum ether, diethyl ether and acetic acid $(80: 30: 1, \mathrm{v} / \mathrm{v})$. Spots were detected by spraying with $50 \% \mathrm{H}_{2} \mathrm{SO}_{4}$, followed by heating at $110^{\circ} \mathrm{C}$ for $25 \mathrm{~min}$. 
Chemicals. Sephadex G-75, G-100, DEAE Sepharose CL-6B and the calibration proteins for estimation of the molecular weight of the enzyme were purchased from Pharmacia Fine Chemicals (Uppsala, Sweden). Hydroxyapatite was obtained from Bio-Rad Laboratories (Richmond, U.S.A). The pI markers were from Oriental Yeast Co., Ltd. (Tokyo, Japan), and Ampholine from LKB-Produkter (Stockholm, Sweden). Triglycerides and monoesters were the products of Tokyo Chemical Industry Co., Ltd. (Tokyo, Japan). Diolein, 1,2-diolein, 1,3diolein and 1-monoolein were purchased from Sigma Chemical Co. (St. Louis, U.S.A.). Oleic acid was from Nippon Yushi Co. (Tokyo, Japan).

\section{RESULTS AND DISCUSSION}

\section{Enzyme purification}

A summary of the purification of the lipase is presented in Table I. The enzyme was purified about 150 -fold with a yield of $15.0 \%$ and a specific activity of about $3000 \mathrm{U} / \mathrm{mg}$ protein. Based on the fact that only one peak of enzyme activity was observed in the elution patterns for all the columns used, as in the case of the $H$. lanuginosa S-38 lipase ${ }^{19)}$ we concluded that H. lanuginosa No. 3 also produced only one kind of lipase. Several authors ${ }^{20,21)}$ have reported the existence of more than one lipase in a particular organism.

\section{Purity of the enzyme}

Polyacrylamide gel electrophoresis of the enzyme solution from step (e) (Fig. 1, fractions $29 \sim 35$ ) showed a single protein band (Fig.

Table I. Purification of the Lipase

\begin{tabular}{lccccc}
\hline \multicolumn{1}{c}{ Steps } & $\begin{array}{c}\text { Total } \\
\text { protein } \\
(\mathrm{mg})\end{array}$ & $\begin{array}{c}\text { Total } \\
\text { activity } \\
(\mathrm{U})\end{array}$ & $\begin{array}{c}\text { Specific } \\
\text { activity } \\
(\mathrm{U} / \mathrm{mg})\end{array}$ & $\begin{array}{c}\text { Yield } \\
(\%)\end{array}$ & $\begin{array}{c}\text { Purity } \\
\text { (fold) }\end{array}$ \\
\hline $\begin{array}{l}\text { Culture broth } \\
\text { Acetone powder } \\
\quad(80 \%)\end{array}$ & 776 & 15,700 & 20.2 & 100 & 1.00 \\
$\begin{array}{l}\text { Sephadex G-75 } \\
\text { DEAE Sepharose }\end{array}$ & 1720 & 15,300 & 47.8 & 97.5 & 2.40 \\
$\quad$ CL-6B (1) & 11.3 & 14,300 & 79.9 & 91.1 & 3.96 \\
$\begin{array}{c}\text { DEAE Sepharose } \\
\text { CL-6B (2) }\end{array}$ & 2.46 & 4,950 & 792 & 57.0 & 39.2 \\
Hydroxyapatite & 0.78 & 2,360 & 3,030 & 30.0 & 95.0 \\
\hline
\end{tabular}

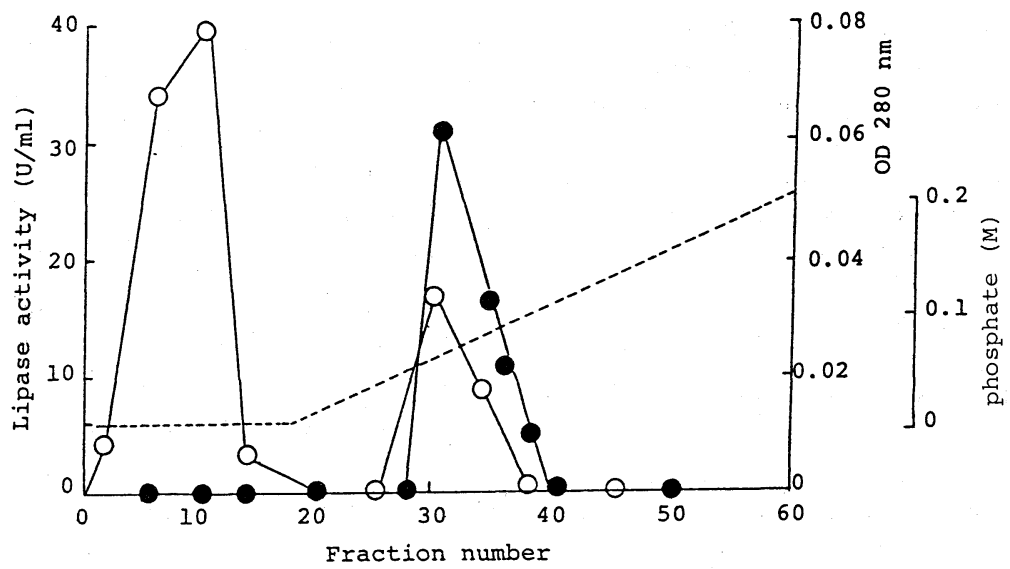

FIG. 1. Elution Profile of Lipase Activity from a Hydroxyapatite Column.

The enzyme solution from step (d) (see text) was applied on a column $(0.9 \times 16.5 \mathrm{~cm})$ of hydroxyapatite. The column was eluted with a linear gradient of 0.01 to $0.2 \mathrm{M}$ sodium phosphate $(\mathrm{pH} 7.0)$. Flow rate, $17.6 \mathrm{ml} / \mathrm{hr}$; fraction volume, $4.0 \mathrm{ml}$; , lipase activity; $\bigcirc$, absorbance at $280 \mathrm{~nm} ;----$, phosphate concentration. 


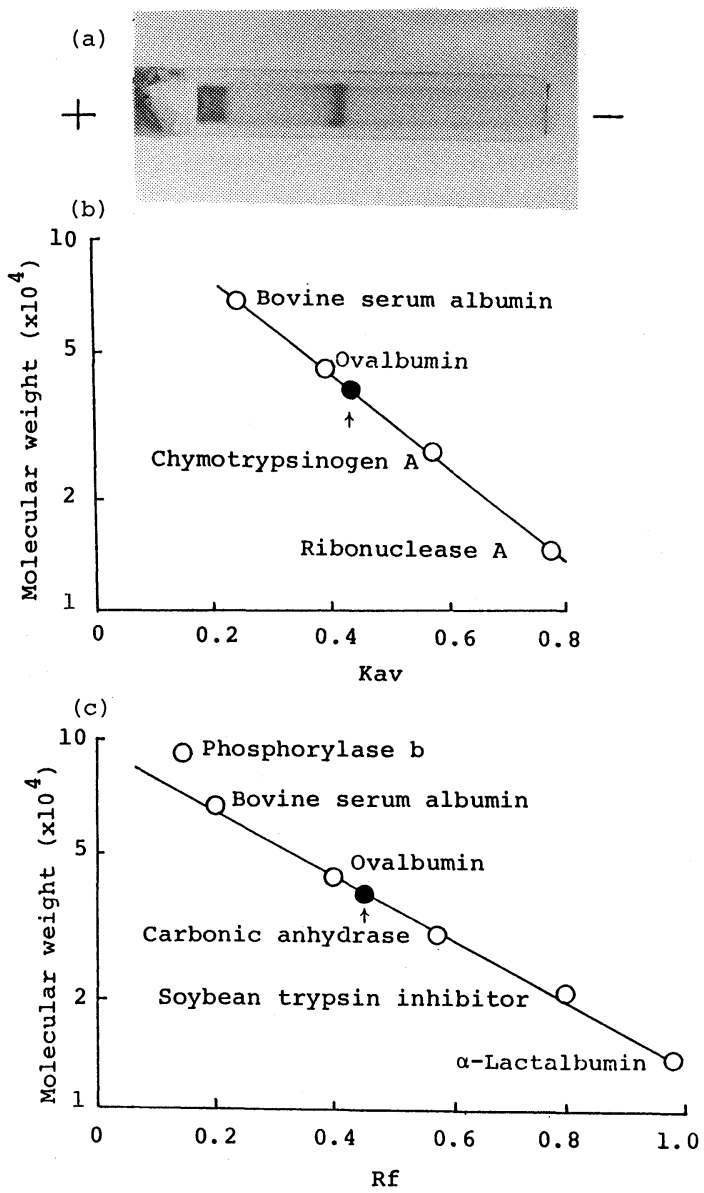

FIg. 2a. Polyacrylamide Gel Electrophoresis of the Purified Enzyme from Step (e).

2b. Molecular Weight Estimation of the Enzyme by Gel Filtration.

The enzyme solution was placed on a Sephadex G-100 column $(1.6 \times 60 \mathrm{~cm})$ equilibrated with $0.05 \mathrm{M}$ sodium phosphate buffer ( $\mathrm{pH} 6.8$ ). The column was eluted with the same buffer at the rate of $18 \mathrm{ml} / \mathrm{hr}$. Fractions of $1.5 \mathrm{ml}$ of the eluate were collected. The calibration curve was obtained with the following marker proteins (molecular weight): ribonuclease $A(13,700)$; chymotrypsinogen $A$ $(25,000)$; ovalbumin $(43,000)$; and bovine serum albumin $(67,000)$. The arrow shows the position of the purified enzyme; $K a v$, relative elution volume.

2c. Molecular Weight Estimation of the Enzyme by SDS-PAGE.

The enzyme and marker proteins were subjected to electrophoresis as described in the text. The marker proteins (molecular weight) used were as follows: phosphorylase $b$ $(94,000)$; bovine serum albumin $(67,000)$; ovalbumin $(43,000)$; carbonic anhydrase $(30,000)$; soybean trypsin inhibitor $(21,100)$; and $\alpha$-lactalbumin $(14,400)$. The arrow shows the position of the purified enzyme; $R f$, relative mobility. 2a).

Molecular weight and isoelectric point of the enzyme

The molecular weight of the enzyme estimated by gel filtration on Sephadex G-100 was found to be 39,000 (Fig. 2b), which was similar to that determined on SDS-PAGE (Fig. 2c). The results suggested that the enzyme from $H$. lanuginosa No. 3 was a monomeric form. Liu et al. ${ }^{22)}$ found that the molecular weight of the H. lanuginosa S-38 lipase was much lower, i.e., about 27,500. Semeriva et al. ${ }^{23)}$ and Iwai et $a l .^{21)}$ reported that various kinds of lipase from Rhizopus arrhizus and Penicillium cyclopium, respectively, are monomeric enzymes. The isoelectric point of the lipase of $H$. lanuginosa No. 3 was found to be 6.6. Great variation with respect to the pI value has been observed among microbial lipases reported so far. ${ }^{24,25)}$

\section{Effects of temperature and $\mathrm{pH}$ on the activity}

The enzyme activity was determined at various temperatures, from 30 to $80^{\circ} \mathrm{C}$. The optimum temperature of the enzyme reaction (30 min) was $45^{\circ} \mathrm{C}$ (Fig. 3a). The thermal stability was investigated by determining the residual activity (at $45^{\circ} \mathrm{C}, 30 \mathrm{~min}$ ) after leaving the enzyme solution $(\mathrm{pH} \mathrm{7.0)}$ at various temperatures, from 30 to $80^{\circ} \mathrm{C}$, for $10 \mathrm{~min}$. The enzyme was stable up to $65^{\circ} \mathrm{C}$, retaining $100 \%$ activity (data not shown). Thermal stability was also investigated at 45, 60, 65, 70 and $80^{\circ} \mathrm{C}$ with a longer incubation period $(24 \mathrm{hr})$. The enzyme was found to be stable for $24 \mathrm{hr}$ at $45^{\circ} \mathrm{C}$, for about $20 \mathrm{hr}$ at $60^{\circ} \mathrm{C}$ for about $60 \mathrm{~min}$ at $65^{\circ} \mathrm{C}$ (Fig. 4). The enzyme activity disappeared on treatment for $18 \mathrm{hr}$ at $65^{\circ} \mathrm{C}$ or for $1 \mathrm{hr}$ at $70^{\circ} \mathrm{C}$. The $H$. lanuginosa S-38 enzyme $^{19}$ ) showed a lower thermal stability when compared to that of the $H$. lanuginosa No. 3 one. The optimal temperature and temperature stability pattern of the lipase from $H$. lanuginosa No. 3 were similar to those observed for those of Aspergillus niger $^{5)}$ (opt. temp., $25^{\circ} \mathrm{C}$; temp. stability, $55^{\circ} \mathrm{C}$ ) and Staphylococcus aureus ${ }^{26}$ (opt. temp., $45^{\circ} \mathrm{C}$; temp. stability, $65^{\circ} \mathrm{C}$ ). 

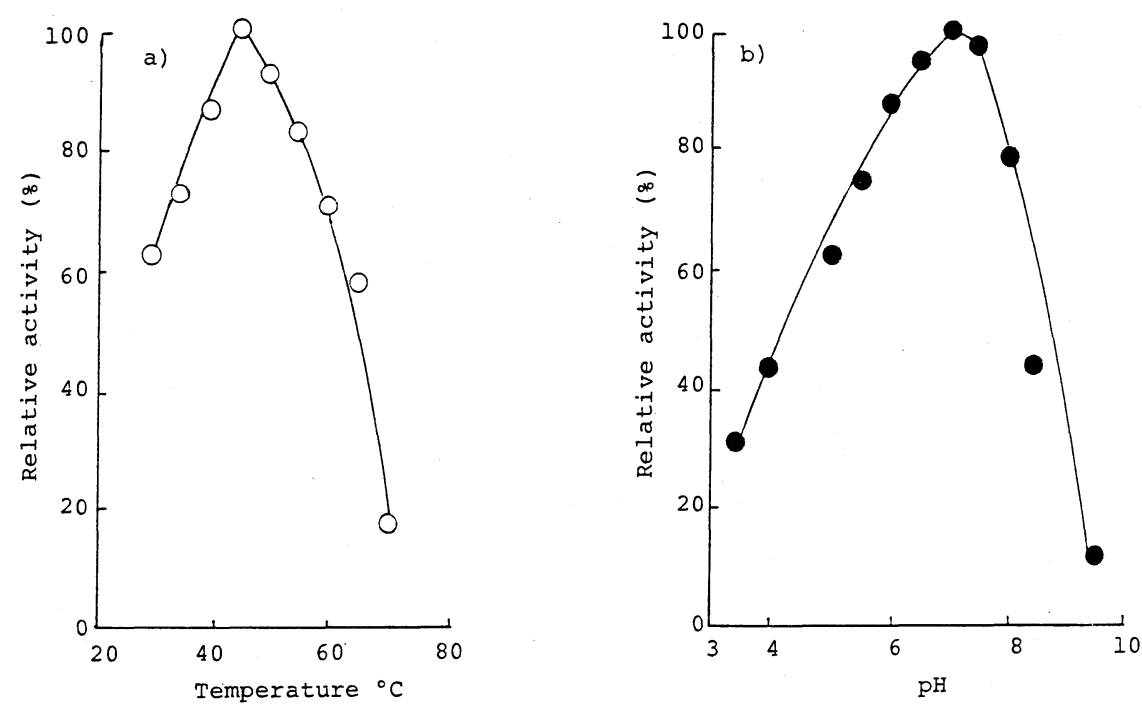

FIG. 3. Effects of Temperature and pH on the Enzyme Activity.

The enzyme reaction was carried out at various temperatures and pHs. The activity was determined by the olive oil-PVA emulsion method. The buffer systems were (0.2 M): McIlvaine buffer ( $\mathrm{pH} 3 \sim 7.5$ ). Atkins and Pantin buffer $(\mathrm{pH} 8 \sim 11)$ and $\mathrm{Na}_{2} \mathrm{HPO}_{4}-\mathrm{NaOH}(\mathrm{pH} 11 \sim 12)$. a) optimum temperature; b) optimum pH.

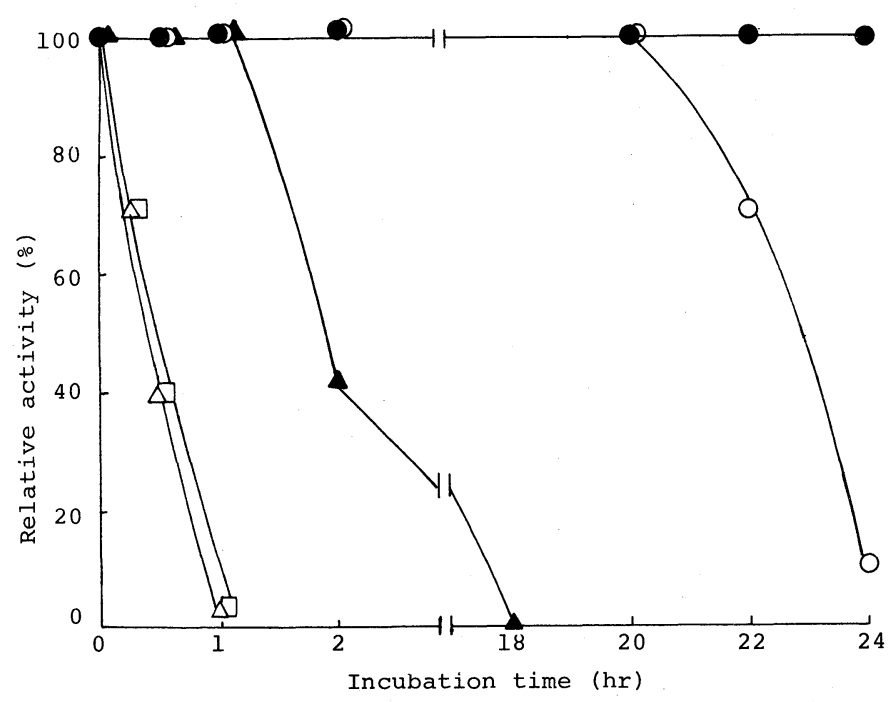

FIG. 4. Temperature Stability of the Enzyme with Respect to the Incubation Period.

The enzyme-buffered solution ( $\mathrm{pH} 7.0$ ) was incubated for the indicated periods and then the residual activity was determined by the olive oil-PVA emulsion method., $45^{\circ} \mathrm{C} ; \mathrm{O}, 60^{\circ} \mathrm{C} ; \boldsymbol{\Delta}, 65^{\circ} \mathrm{C} \square, 70^{\circ} \mathrm{C} ; \triangle, 80^{\circ} \mathrm{C}$.

The optimum $\mathrm{pH}$ of the enzyme reaction $\left(45^{\circ} \mathrm{C}, 30 \mathrm{~min}\right)$ was determined at various $\mathrm{pHs}$, from 3 to 10 . The highest activity was seen at pH 7.0 (Fig. 3b). The enzyme was relatively stable over the $\mathrm{pH}$ range of 5 to 9 (incubation conditions: $45^{\circ} \mathrm{C}, 24 \mathrm{hr}$ ) (data not shown). The optimum $\mathrm{pH}$ and temperature of the purified enzyme were found to be similar to those of the crude enzyme preparation. 
Effects of metal ions and other reagents on the activity

The effects of various metal ions and reagents at $1 \mathrm{~mm}$ concentration on the enzyme activity were investigated. Alkali metal ions $\left(\mathrm{Li}^{+}, \mathrm{K}^{+}\right.$or $\left.\mathrm{Ca}^{2+}\right)$ enhanced the activity while $\mathrm{Co}^{2+}, \mathrm{Ni}^{2+}, \mathrm{Cu}^{2+}, \mathrm{Sn}^{2+}$ and $\mathrm{Hg}^{2+}$ showed inhibitory effects (Table II). Other metal ions did not significantly affect the activity. Slight effects were observed with $\mathrm{Zn}^{2+}, \mathrm{Mg}^{2+}$, sulfhydryl reagents, EDTA and SDS. Almost the same results were obtained by other workers for similar lipases. ${ }^{6.7)}$

\section{Substrate specificity}

In order to obtain a clearer picture of the substrate specificity of the enzyme, the lipolytic action of the enzyme was investigated in the following experiments:

(a) Action on natural oils. The enzymatic hydrolysis of various natural oils was examined under the following conditions: $45^{\circ} \mathrm{C}$, $2 \mathrm{hr}$, with shaking at $100 \mathrm{osc} / \mathrm{min}, \mathrm{pH} \mathrm{7.0.} \mathrm{As}$ shown in Table III, coconut oil, which contains a relatively high proportion of lauric acid (C12), was hydrolyzed most rapidly. Palm oil (C16 and $\left.\Delta^{9}-\mathrm{C} 18\right)$ and corn oil $\left(\Delta^{9}-\right.$
C18 and $\left.\Delta^{9.12}-\mathrm{C} 18\right)$ were hydrolyzed more rapidly than olive oil $\left(\Delta^{9}-\mathrm{C} 18\right)$. However, the degree of hydrolysis was also affected by the

TAble II. EfFects of Metal Ions and Other REAGENTS ON THE ENZYME ACTIVITY

\begin{tabular}{|c|c|}
\hline $\begin{array}{l}\text { Metal ions } \\
\quad(1 \mathrm{~mm})^{a}\end{array}$ & $\begin{array}{c}\text { Relative activity } \\
(\%)\end{array}$ \\
\hline $\mathrm{Co}^{2+}$ & 44 \\
\hline $\mathrm{Li}^{+}$ & 111 \\
\hline $\mathrm{Zn}^{2+}$ & 83 \\
\hline $\mathrm{Cu}^{2+}$ & 8 \\
\hline $\mathrm{Mg}^{2+}$ & 83 \\
\hline $\mathrm{Ni}^{2+}$ & 67 \\
\hline $\mathrm{Mn}^{2+}$ & 101 \\
\hline $\mathrm{Hg}^{2+}$ & 17 \\
\hline $\mathrm{Fe}^{2+}$ & 95 \\
\hline $\mathrm{Sn}^{2+}$ & 69 \\
\hline $\mathrm{Ca}^{2+}$ & 111 \\
\hline $\mathrm{Pb}^{2+}$ & 94 \\
\hline $\mathrm{Ba}^{2+}$ & 92 \\
\hline $\mathrm{K}^{+}$ & 129 \\
\hline EDTA & 89 \\
\hline pCMB & 98 \\
\hline SDS & 108 \\
\hline None & 100 \\
\hline
\end{tabular}

The relative activity $(\%)$ was calculated relative to that in the case of the reaction without the addition of any metal ions, which was taken as $100 \%$.

a Concentration in the reaction mixture.

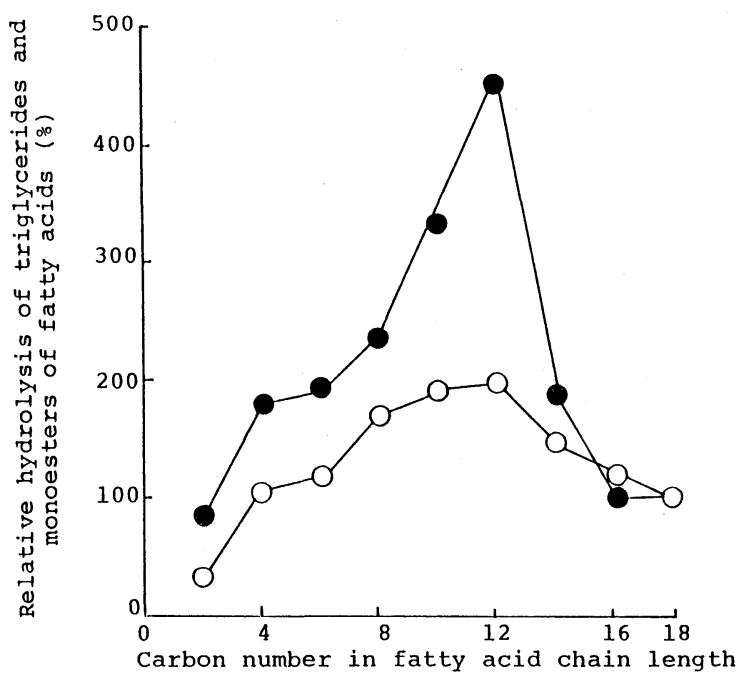

Fig. 5. Substrate Specificity of the Enzyme as to the Hydrolysis of Triglycerides and Monoesters of Saturated Fatty Acids.

The reaction conditions were given in the text. Hydrolysis $(\%)$ was calculated relative to that of triolein (for triglycerides) and methyl oleate (for monoesters), which was taken as $100 \%$.

, triglycerides; $\bigcirc$, monoesters. 
amounts of other fatty acid components present in the oils.

(b) Action on triglycerides and monoesters of saturated fatty acids. The results obtained as to the action of the enzyme on these substrates are shown in Fig. 5. It was found that the extent of hydrolysis of either triglycerides or

Table III. Substrate Specificity of the Enzyme as to THE Hydrolysis of Natural OILS

\begin{tabular}{lc}
\hline $\begin{array}{c}\text { Natural oils } \\
(1 \mathrm{ml})\end{array}$ & $\begin{array}{c}\text { Relative hydrolysis } \\
(\%)\end{array}$ \\
\hline Olive oil & 100 \\
Peanut oil & 73 \\
Corn oil & 179 \\
Soybean oil & 134 \\
Palm oil & 195 \\
Castor oil & 32 \\
Cottonseed oil & 161 \\
Coconut oil & 274 \\
Lard oil & 149 \\
\hline
\end{tabular}

Relative hydrolysis $(\%)$ was calculated relative to that of olive oil, which was taken as $100 \%$. Reaction conditions: see the text. monoesters with short chain fatty acids ( $\mathrm{C} 4$ or C6) was almost the same as that of $\mathrm{C} 16$ or C18. The rate of hydrolysis of triglycerides was found to be much higher than that of monoesters under the conditions examined. As to the action on triglycerides and monoesters, the enzyme showed a higher specificity towards

Table IV. Action of the Enzyme on Esters of Unsaturated C18 Fatty AcIDS

\begin{tabular}{lc}
\hline \multicolumn{1}{c}{ Esters } & $\begin{array}{c}\text { Relative hydrolysis } \\
(\%)\end{array}$ \\
\hline Triolein & 100 \\
Methyl oleate & 50 \\
Methyl linoleate & 13.2 \\
Methyl linolenate & 34.2 \\
Tween 80 & 121.1 \\
Tween 85 & 10.5 \\
Span 80 & 7.9 \\
Span 85 & 39.5 \\
\hline
\end{tabular}

Relative hydrolysis ( $\%$ ) was calculated relative to that of triolein, which was taken as $100 \%$. Reaction mixture and conditions: see Table III.

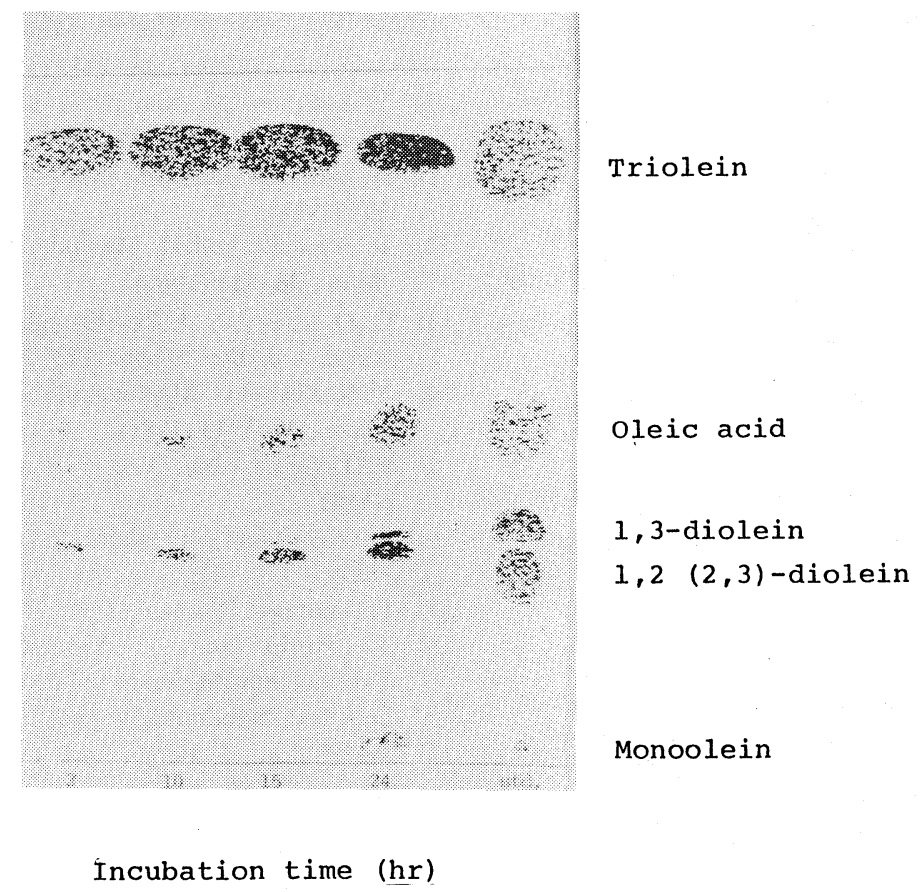

FIG. 6. Thin Layer Chromatography of the Hydrolyzate of Triolein Obtained through the Action of the Enzyme.

The reaction conditions were given in the text. 
C12 containing substrates (trilaurin or methyl laurate). These results were in good agreement with those in Table III. Iwai et al. ${ }^{21)}$ found that the rate of the enzymatic reaction of the lipase from P. cyclopium depended on the phase of the substrate at the temperature examined, i.e., whether the substrate was in a solid or liquid state.

Lipase hydrolysis of triglycerides is a reversible, multistage reaction, which depends on the available interfacial area of the substrates, thus giving a complex overall reaction. ${ }^{27.28)}$ Due to such difficulties, reports regarding kinetic studies have been very scarce. However, the affinity of this Humicola enzyme towards several substrates (triolein, trilaurin, methyl oleate and methyl laurate) was studied under the following conditions: $6 \sim 50 \mathrm{mg}$ trilaurin/ml; $40 \mathrm{U}$ of enzyme; $45^{\circ} \mathrm{C}$; $\mathrm{pH} 7.0$; $150 \mathrm{osc} / \mathrm{min}$ in L-tubes, with a total volume of $5.0 \mathrm{ml}$. The $\mathrm{Km}$ value for trilaurin was found to be $14.2 \mathrm{mg} / \mathrm{ml}$ (data not shown). Trilaurin was previously found to be the most rapidly hydrolyzed by the enzyme (see Fig. 5). Other substrates were found to be misleading or unsuccessful.

(c) Action on esters of unsaturated C18 fatty acids. Inspite of its low hydrolytic specificity for C18 fatty acids (Fig. 5), the hydrolytic pattern of the enzyme might also be affected by the degree of unsaturation of $\mathrm{C} 18$ fatty acids. Various esters of unsaturated $\mathrm{C} 18$ fatty acids were investigated, and polyethylene sorbitan monooleate (Tween 80) was found to be hydrolyzed to a higher extent than triolein (Table IV). Low hydrolytic activity was observed with esters of a higher degree of unsaturation such as methyl linoleate $\left(\Delta^{9.12}\right)$ and methyl linolenate $\left(\Delta^{9.12 .15}\right)$.

\section{Positional specificity}

With respect to the hydrolyzate of triolein (Fig. 6), obtained through the action of the lipase from $H$. lanuginosa No. 3, 1,2 (2,3)diolein was detected but 1,3-diolein was not. From these facts it is clear that the lipase did not hydrolyze the ester bond at position 2 of the triglycerides, indicating that the enzyme is a 1,3 positional specific lipase. The Aspergillus niger and Rhizopus delemer enzymes ${ }^{29}$ were also found to exhibit a similar feature. However, on prolonged incubation $(24 \mathrm{hr}), 1,3-$ diolein was also slightly detected, which might be due to the spontaneous isomerization of the partial glycerides. ${ }^{30 \text { ) }}$

\section{REFERENCES}

1) K. Nagaoka and Y. Yamada, Agric. Biol. Chem., 33, 986 (1969).

2) M. Sugiura, M. Isobe, N. Muroya and T. Yamaguchi, Agric. Biol. Chem., 38, 947 (1974).

3) M. Iwai and Y. Tsujisaka, Agric. Biol. Chem., 38, 1241 (1974).

4) Y. Ota, K. Gomi, S. Kato, T. Sugiura and Y. Minoda, Agric. Biol. Chem., 46, 2885 (1982).

5) J. Fukumoto, M. Iwai and Y. Tsujisaka, J. Gen. Appl. Microbiol., 9, 353 (1963).

6) J. Fukumoto, M. Iwai and Y. Tsujisaka, J. Gen. Appl. Microbiol., 10, 257 (1964).

7) Y. Horiuti and M. Imamura, J. Biochem., 81, 1639 (1977).

8) S. Oi, A. Sawada and Y. Satomura, Agric. Biol. Chem., 31, 1357 (i967).

9) N. Watanabe, Y. Ota, Y. Minoda and K. Yamada, Agric. Biol. Chem., 41, 1356 (1977).

10) Y. Tsujisaka, M. Iwai and Y. Tominaga, Agric. Biol. Chem., 37, 1457 (1973).

11) H. Motai, E. Ichishima and F. Yoshida, Nature, 210 , 308 (1966).

12) K. Yamada and H. Machida, Nippon Nôgeikagaku Kaishi, 36, 858 (1962).

13) O. H. Lowry, N. J. Rosebrough, A. L. Farr and R. J. Randall, J. Biol. Chem., 193, 265 (1951).

14) Y. Kokusho, H. Machida and S. Iwasaki, Agric. Biol. Chem., 46, 1743. (1982).

15) B. J. Davis, Ann. New York Acad. Sci., 121, 404 (1964).

16) K. Weber and M. Osborn, J. Biol. Chem., 244, 4406 (1969).

17) P. Andrews, Biochem. J., 91, 222 (1964).

18) T. Horio and J. Yamashita, "Fundamental Experimental Methods for Proteins and Enzymes," 2nd. Ed., Nanko-do, Tokyo, 1983, p. 333.

19) W. H. Liu, T. Beppu and K. Arima, Agric. Biol. Chem., 37, 157 (1973).

20) K. Nagaoka and Y. Yamada, Agric. Biol. Chem., 37, 2791 (1973)

21) M. Iwai, S. Okumura and Y. Tsujisaka, Agric. Biol. Chem., 39, 1063 (1975).

22) W. H. Liu, T. Beppu and K. Arima, Agric. Biol. Chem., 37, 2493 (1973). 
23) M. M. Semeriva, G. Benzonana and P. Desnuelle, Biochim. Biophys. Acta, 191, 598 (1969).

24) F. Yoshida, H. Motai and E. Ichishima, Biochim. Biophys. Acta, 154, 586 (1968).

25) M. Isobe and M. Sugiura, Chem. Pharm. Bull., 25, 1980 (1977).

26) Y. Ota, "Handbook of Microbiology," Vol. III, ed. by A. I. Laskin and H. A. Lechevalier, CRC Press, Inc., Cleveland, Ohio, 1973, p. 625.

27) P. Desnuelle, "The Enzymes," Vol. 7, 3rd Ed., ed. by P. D. Boyer, Academic Press, New York, 1972, p. 575 .

28) Y. Kosugi and H. Suzuki, J. Ferment. Technol., 61, 287 (1983).

29) S. Okumura, M. Iwai and Y. Tsujisaka, Agric. Biol. Chem., 40, 655 (1976).

30) A. R. Macrae, "Microbial Enzymes and Biotechnology," ed. by W. H. Forgarty, Appl. Sci. Publishers, New York, 1983, p. 225. 